\title{
Study of the physical and physicochemical characteristics of fruits of the licuri palm (Syagrus coronata (Mart.) Becc.) found in the Atlantic Forest of Minas Gerais, Brazil
}

\author{
Galdino Xavier de PAULA FILHO ${ }^{1 *}$, Tibério Fontenelle BARREIRA ${ }^{1}$, Vívian Cristina da Cruz RODRIGUES ${ }^{1}$, \\ Leandro de Morais CARDOSO ${ }^{2}$, Hércia Stampini Duarte MARTINO ${ }^{1}$, Helena Maria PINHEIRO-SANT'ANA ${ }^{1}$
}

\begin{abstract}
The Atlantic Forest has species of native fruits, consumed fresh and processed, which have an important contribution to food sovereignty of families that consume it. This study examined the physical and physicochemical characteristics, proximate composition, concentration of carotenoids, vitamin C, vitamin E and minerals in the pulp and kernels of fruits of licuri (Syagrus coronata (Mart.) Becc.). Titratable acidity was analyzed by volumetric neutralization, soluble solids by refractometry, proteins by the micro-Kjeldahl method, lipids by gravimetry using soxhlet, dietary fiber by non-enzymatic gravimetry, carotenoids and vitamin $\mathrm{C}$ by HPLC-DAD, vitamin E by HPLC-fluorescence, and minerals by ICP-AES. Pulp were a source of Zn

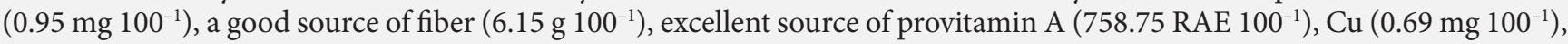
Fe $\left(3.81 \mathrm{mg} 100^{-1}\right)$, Mn (3.40 mg $\left.100^{-1}\right)$ and $\mathrm{Mo}\left(0.06 \mathrm{mg} 100^{-1}\right)$. The kernel were a source of Fe $\left(3.36 \mathrm{mg} 100^{-1}\right)$ and excellent

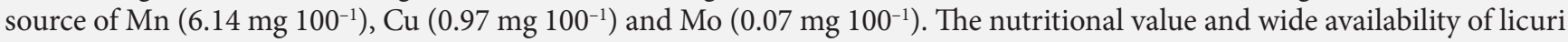
fruit make it an important resource for reducing food insecurity and improving nutrition of the rural population and other individuals who have access to it.
\end{abstract}

Keywords: native fruits; food resources; vitamins; carotenoids; minerals.

Practical Application: Shows the physical and chemical composition (soluble solids, $\mathrm{pH}$ and Titratible acidity), chemical composition (moisture content, total dietary fiber, lipids, proteins, carbohydrates and ash), carotenoids ( $\alpha$-carotene, $\beta$-carotene, $\beta$-cryptoxanthin and lycopene), vitamin $C$ (ascorbic acid and dehydroascorbic acid), vitamin $\mathrm{E}$ ( $\alpha-, \beta-, \gamma^{-}, \delta$-; tocopherol and tocotrienol) and minerals ( $\mathrm{P}, \mathrm{K}, \mathrm{Ca}, \mathrm{Mg}, \mathrm{Cu}, \mathrm{Fe}, \mathrm{Zn}, \mathrm{Mn}, \mathrm{Na}, \mathrm{Cr}, \mathrm{Se}$ and $\mathrm{Mo}$ ) in fruits of licuri palm, and their contribution to the Daily Recommendation of Nutrients in adults 19 to 30 years.

\section{Introduction}

The Atlantic Forest covers an extensive area of the Brazilian territory and shows great variation in climate, soil, fauna and flora. Native fruit species of this biome have been explored for several purposes, including human consumption in natura or as juices, jams and jellies (Lorenzi et al., 2006). These fruit species are an alternative to improve the supply of nutrients in the population (Pilla \& Amorozo, 2009). However, some species are still underutilized due to lack of scientific and technical studies on their nutritional value (Kinupp \& Barros, 2004; Rockenbach et al., 2008).

Fruit consumption plays an important role in human nutrition, contributing to the increase in life expectancy and prevention of chronic non-communicable diseases, especially due to the presence of minerals, vitamins and dietary fiber (Cardoso et al., 2013b). Furthermore, the protective effect exerted by fruit is attributed to the presence of compounds capable of capturing free radicals (antioxidants), highlighting vitamins, phenolic compounds and carotenoids (Betoret et al., 2011).

Syagrus coronata belongs to the botanical family Arecaceae and is one of the main native palm species of the Atlantic Forest.

The fruit is a fibrous drupe with ovoid and fleshy endoderm. While green, it has liquid endosperm which becomes solid in the ripening process, giving rise to the kernels. When ripe, the pulp (exocarp and mesocarp) presents a light yellow to orange coloring, depending on the maturation stage. Ripe fruits have yellow, sticky and sweet pulp (Drumond, 2007).

Although the licuri palm has played a role in the eating habits of the rural population for generations, information in literature on its nutritional value is scarce. The limited information available refers to its proximate composition, physicochemical composition and some vitamins in fruits from northeastern Brazil, where it is widely used in the manufacture of couscous and coconut candy, the oil is used in cooking, and the kernels serve for both human consumption as well as use in poultry feed (Rufino et al., 2008; Santos et al., 2012).

Given the above, our study sought to analyze the physical and physico-chemical characteristics, proximate composition, and concentration of carotenoids, vitamin $\mathrm{C}$, vitamin $\mathrm{E}$ and minerals in licuri fruits found in rural Viçosa, Minas Gerais. 


\section{Materials and methods}

\subsection{Collection and preparation of the samples}

The fruits analyzed were collected in March 2013, in the municipality of Viçosa (latitude $20^{\circ} 45^{\prime} 14^{\prime \prime} \mathrm{S}$ and longitude $42^{\circ} 52^{\prime} 44^{\prime \prime}$ W), Minas Gerais, Brazil. Samples were collected in five different rural locations, which characterized the five repetitions. In each repetition approximately $1.5 \mathrm{~kg}$ of fruits from at least three different plants were used for obtantion of the pulp and $2.5 \mathrm{~kg}$ for obtantion of the kernels

The samples were transported from the harvest site to the laboratory, protected in styrofoam boxes, within two hours after collection. The fruits were washed under tap water to remove dirt and then dried with paper towels. Pulp of the licuri fruit (exocarp and mesocarp) was manually separated from the rest of the fruit (endocarp and kernel) with the aid of a spatula, while the kernel was broken with the aid of a hammer and spatula, separating it from the fruit endocarp and mesocarp.

Next, the pulp and kernel were homogenized separately in a food processor (Philips ${ }^{\circledR}$, RI 7625, Brasil), packaged in polyethylene bags wrapped in aluminum foil and stored in a freezer $\left(-18 \pm 1^{\circ} \mathrm{C}\right)$ until performing the analyses.

\subsection{Physical characterization}

Measurements of length and diameter were obtained for 20 fruits using a digital caliper (Mitutoyo, M5, Brazil). Individual direct weighing of the total fruit mass (FM) and edible portion mass (EP), of the pulp and of the kernel was performed on a semi-analytical balance (Gehaka, BG 2000, Brazil). Then the yield of the edible part of the pulp and kernel was calculated using the following equation: (EM/FM) x 100.

\subsection{Chemical analyses}

The chemical analyses were performed, in three repetitions, at the Food Analysis and Vitamin Analysis Laboratories of the Department of Nutrition and Health, Federal University of Viçosa, Brazil.

Titratable acidity (TA) was analyzed by volumetric neutralization and soluble solids (SS) by refractometry, $\mathrm{pH}$ by direct potentiometry (Instituto Adolfo Lutz, 2005), moisture by gravimetric analysis after oven drying (SP Labor ${ }^{\circledR}$, SP 200, Brazil) at $105^{\circ} \mathrm{C}$, ash by gravimetry after burn in a muffle furnace (Quimis, 318, Brasil) at $550{ }^{\circ} \mathrm{C}$, proteins by the micro-Kjeldahl method, lipids by gravimetry after ethyl ether extraction using soxhlet and total dietary fiber (TDF) by non-enzymatic gravimetry (Association of Official Analytical Chemists, 2010). Carbohydrates were calculated as the difference using the equation: [100 - \% moisture - $\%$ lipids - $\%$ protein - $\%$ TDF - $\%$ ash]. The total energetic value was estimated considering the conversion factors of $4 \mathrm{kcal} \mathrm{g}^{-1}$ of protein or carbohydrate and $9 \mathrm{kcal} \mathrm{g}^{-1}$ of lipids (Frary \& Johnson, 2005).

\subsection{Extraction and analysis of carotenoids and vitamins}

Preparation and analysis of carotenoids and vitamins were performed in five repetitions using recently validated methods (limits of detection and quantification, tests of repeatability and recovery) in our laboratory for the analysis of fruits from the Brazilian Cerrado (Cardoso et al., 2013a).

During collection, extraction and analysis, fruits were protected from light to prevent the loss of vitamins and carotenoids. For the extraction of carotenoids and vitamins, the following reagents were used for analysis: acetone, petroleum ether and glacial acetic acid (Vetec, Brazil). For analysis of the compounds the following HPLC grade reagents were used: hexane, isopropanol, ethyl acetate, methanol and acetonitrile (Tedia, Brazil).

Analysis of carotenoids and vitamin $\mathrm{C}$ were carried out in a High Performance Liquid Chromatography system (HPLC) (Shimadzu, SCL 10AT VP, Japan) composed of a high-pressure pump (LC 10AT VP), autosampler with $500 \mu \mathrm{L}$ loop (SIL-10AF), and diode array detector (DAD) (SPD-M10A). In the analysis of vitamin E, an HPLC system was used (Shimadzu, SCL 10AD VP, Japan) composed of a high-pressure pump valve for a low pressure quaternary gradient (LC 10AD VP), autosampler with $50 \mu \mathrm{L}$ loop (SIL-10AF), and fluorescence detector (RF-10A XL).

\section{Carotenoids}

Occurrence of the following carotenoids was investigated: $\alpha$-carotene, $\beta$-carotene, $\beta$-cryptoxanthin and lycopene in the pulp and kernel of the licuri fruit. Carotenoids were extracted in acetone and transferred to petroleum ether (Rodriguez-Amaya et al., 1976). The chromatographic conditions developed by Pinheiro-Sant'Ana et al. (1998) were used: HPLC-DAD system, Phenomenex Gemini chromatography column RP-18 (250 mm $\times 4.6 \mathrm{~mm}, 5 \mu \mathrm{m}$ i.d. $)$, fitted with a Phenomenex ODS guard column $(4 \mathrm{~mm} \times 3 \mathrm{~mm})$; mobile phase composed of methanol: ethyl acetate: acetonitrile $(70: 20: 10, \mathrm{v} / \mathrm{v} / \mathrm{v})$ and mobile phase flow of $1.7 \mathrm{ml} \mathrm{min}^{-1}$. The run time was approximately 12 minutes and the chromatograms were obtained at $450 \mathrm{~nm}$.

The amount of vitamin A was calculated according to the recommendations of the Institute of Medicine (2011), wherein 1 Retinol Activity Equivalent (RAE) corresponds to $1 \mu \mathrm{g}$ of retinol; $12 \mu \mathrm{g}$ of $\beta$-carotene; $24 \mu \mathrm{g}$ of other pro-vitamin carotenoids.

\section{Vitamin C}

Ascorbic acid (AA) and dehydroascorbic acid (DHA) were extracted in a buffer solution (3\% metaphosphoric acid, $8 \%$ acetic acid, $0.3 \mathrm{~N}$ sulfuric acid and $1 \mathrm{mM}$ EDTA) (Campos et al., 2009). Then DHA in the sample was converted to AA using dithiothreitol (Pinheiro-Sant'Ana et al., 1998). For anlaysis of AA the chromatographic conditions proposed by Campos et al. (2009) were used, in the same HPLC system used for carotenoids. The column used was Lichrospher 100 $(250 \times 4 \mathrm{~mm}, 4 \mu \mathrm{m}$ i.d. $)$, equipped with a guard column (Phenomenex ODS, $4 \mathrm{~mm} \times 3 \mathrm{~mm}$ ); mobile phase composed of ultrapure water containing $1 \mathrm{mM} \mathrm{NaH} \mathrm{PO}_{4}, 1 \mathrm{mM}$ EDTA and $\mathrm{pH}$ adjusted to 3.0 with $\mathrm{H}_{3} \mathrm{PO}_{4}$, with isocratic elution at a flow rate of $1.0 \mathrm{~mL}$ minute ${ }^{-1}$. The run time was approximately 8 minutes and the chromatograms were obtained at $245 \mathrm{~nm}$. The DHA concentration was calculated using the equation: $D H A$ concentration $=A A$ concentration after conversion $-A A$ concentration before conversion. 


\section{Vitamin E}

The eight homologues of vitamin $\mathrm{E}$ were investigated in the fruits ( $\alpha-, \beta-, \gamma$ - and $\delta$-tocopherols and tocotrienols). The extraction was performed with a solution of hexane: ethyl acetate $(85: 15, \mathrm{v} / \mathrm{v})$ (Pinheiro-Sant'Ana et al., 2011). The analysis was performed according to Pinheiro-Sant'Ana et al. (2011), using the HPLC system, fluorescence detector $(290 \mathrm{~nm}$ for excitation and $330 \mathrm{~nm}$ for emission), LiChrosorb colum (Si100 Phenomenex $250 \times 4 \mathrm{~mm}, 5 \mu \mathrm{m}$ ) fitted with a guard column (Phenomenex Si100, $4 \mathrm{~mm} \times 3 \mathrm{~mm}$ ), mobile phase - hexane: isopropanol: glacial acetic acid (98.9: 0.6: 0.5, v/v/v), and flow

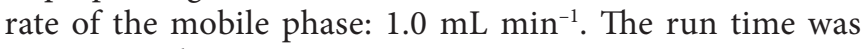
approximately 22 minutes.

\subsection{Determination of minerals}

Minerals (P, K, Ca, Mg, Zn, Mn, Fe, Cu, Na, Cr, Se and Mo) were extracted according to Gomes \& Oliveira (2011), using a solution of nitric acid and perchloric acid (4:1, v/v). The sample suspension was heated to $80^{\circ} \mathrm{C}$ followed by gradual increase up to $200^{\circ} \mathrm{C}$, until the extract reached crystalline staining, and was then withdrawn to cool at room temperature. The crystalline extract was cooled and the volume was completed to $25 \mathrm{~mL}$ with deionized water (Gomes \& Oliveira, 2011). The obtained solution was used to read the concentration of minerals by Inductively Coupled Plasma-Atomic Emission Spectrometry (ICP-AES) (Perkin Elmer, Optima 8300).

Two multielement standard solutions (MESS) were prepared in $100 \mathrm{~mL}$ flasks, due to the different concentrations of minerals in the fruits. MESS 1 was prepared for $\mathrm{Cr}$, Se, Mo, $\mathrm{Zn}, \mathrm{Cu}, \mathrm{Fe}$ and $\mathrm{Mn}$. MESS 2 was prepared for $\mathrm{Na}, \mathrm{P}, \mathrm{Mg}$, Ca and $\mathrm{K}$. In order to quantify the minerals, analytical curves with six points were constructed using mineral standards purchased from Merck ${ }^{\circledR}$ (Brazil). For construction of the curves increasing volumes of MESS 1 ( 0 to $2 \mathrm{~mL}$ ) and MESS 2 ( 0 to $20 \mathrm{~mL}$ ) were used, completed to $50 \mathrm{~mL}$ with distilled water. The maximum concentration of elements in the multielement standard solutions is shown in.

\subsection{Calculation of the potential of the licuri fruit as a nutrient source}

The potential nutritional contribution of the licuri fruit was estimated based on the Recommended Dietary Allowance (RDA) for adult men between 19 and 30 years old according to recommendations of the US Institute of Medicine (2011). The fruit portion was calculated according to the Food Guide for the Brazilian Population (Brasil, 2008) considering the caloric density, where portions of pulp and kernel were equal to 70 and $100 \mathrm{kcal}$, respectively.

The fruit was classified as a "source" of nutrients when supplying $5-10 \%$ of the Dietary Reference Intake (DRI), as a "good source" when supplying 10-20\% of the DRI and "excellent source" when supplying over $20 \%$ of the DRI (Philippi, 2008).

\subsection{Experimental design and statistical analysis of the data}

A completely randomized design was used with five replicates for analysis of carotenoids and vitamins, and three repetitions for physico-chemical analysis and proximate composition.
Descriptive statistics (mean, standard deviation and range of parameters) were used for analysis of the obtained data. To evaluate the linearity range of the analytical standards, data obtained for the peak areas was used to calculate the coefficient of correlation $\left(\mathrm{R}^{2}\right)$. Statistical analysis was performed using the SAS software (Statistical Analysis System), version 9.2 (2008), licensed to the UFV.

\section{Results and discussion}

In the present study we assessed the nutritional value of licuri fruits Syagrus coronata collected in the wild environment. Since they were spontaneously propagated native plants, they may present high genetic variability (Miller \& Gross, 2011). Furthermore, to evaluate the real composition of the fruits and the method in which they are ingested by the population, in our study there was no control of environmental factors (soil, light, ventilation, water availability), which are known to interfere with nutrient concentrations (Bezerra, 2003; Vallilo et al., 2005).

The absence of studies on the licuri fruit made it difficult to compare data obtained in this study with other results. Moreover, it demonstrates the importance of our study and reliable analysis methods used to perform the research.

\subsection{Physical characterization}

The licuri fruit is a fibrous drupe, with ovoid shape, consisting an envelope surrounding the fruit (exocarp). The edible pulp of the fruit, of orangish-red color is the mesocarp. The seed is composed of the endocarp which surrounds the kernel. Between the woody endocarp and the seed is the pellicle, called the tegument (Figure 1).

The pulp constitutes the major fraction of the licuri fruit (54.5\%), while the kernel accounts for only 39.6\% (Table 1). Dimensions of the licuri fruit found were greater than fruit harvested in Mairi, in the state of Bahia, which presented average length and diameter of 2.0 and $1.4 \mathrm{~cm}$, respectively (Crepaldi et al., 2001).

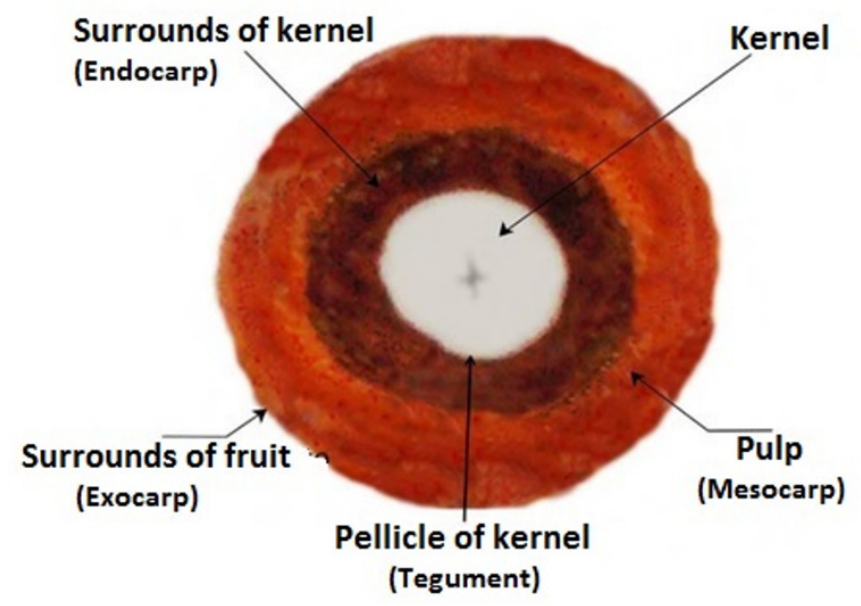

Figure 1. Anatomy/cross section of a mature licuri fruit found in the Atlantic Forest of Minas Gerais, Brazil. 


\subsection{Chemical characterization}

The kernel showed no SS, however the value found in the pulp, as well as its TA, were lower than those found by Miranda (2011) (Table 2).

In the present study, moisture of the pulp and kernel were similar to those observed by Crepaldi et al. (2001) who

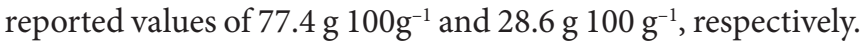
The concentrations of TDF, lipids, proteins and ash were similar to those found by Crepaldi et al. (2001) in the state of Bahia and in Paraíba by Miranda (2011), both also collected from the Atlantic Forest.

The values found for ash in kernels of the licuri fruit in the present study were similar to the kernels of other fruits of the botanical family arecácea, the jelly palm (Butia yatay L.) found in the northern region of the state of Minas Gerais, and the African oil palm (Elaeis guineensis Jacq) from the state of Paraíba, which

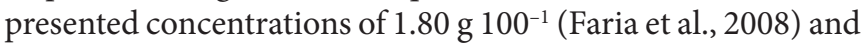

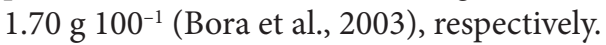

The calorific value of the kernel and the concentration of TDF in the pulp showed to be superior to those of fruits

Table 1. Physical characteristics of the licuri fruits (Syagrus coronata (Mart.) Becc), encountered in the Atlantic Forest of Minas Gerais, Brazil.

\begin{tabular}{ccc}
\hline Variables & Licuri fruit (pulp) & Licuri fruit (kernels) \\
\hline Diameter $(\mathrm{cm})$ & $2.10 \pm 0.07$ & $1.65 \pm 0.06$ \\
Height $(\mathrm{cm})$ & $2.66 \pm 0.14$ & $2.22 \pm 0.06$ \\
Mass $(\mathrm{g})$ & & \\
Fruit & $7.92 \pm 0.61$ & $5.67 \pm 0.08$ \\
Seeds & $4.17 \pm 0.57$ & -- \\
Peel & -- & $3.41 \pm 0.10$ \\
Pulp & $3.74 \pm 0.17$ & $2.26 \pm 0.12$ \\
Yield $(\%)$ & $54.46 \pm 3.44$ & $39.63 \pm 1.97$ \\
\hline
\end{tabular}

Values are expressed in fresh matter (mean of twenty fruits and kernels \pm standard deviation)

Table 2. Chemical characteristics and caloric density of licuri fruits (Syagrus coronata (Mart.) Becc) encountered in the Atlantic Forest of Minas Gerais, Brazil.

\begin{tabular}{ccc}
\hline Variables & Licuri fruit (pulp) & Licuri fruit (kernels) \\
\hline Soluble solids $\left({ }^{\circ}\right.$ Brix) & $7.93 \pm 0.03$ & nd \\
Titratible acidity & $0.63 \pm 0.22$ & $0.51 \pm 0.06$ \\
(g of citric acid $\left.100 \mathrm{~g}^{-1}\right)$ & & -- \\
SS/TA ratio & $12.6 \pm 0.14$ & $6.72 \pm 0.06$ \\
pH & $5.16 \pm 0.09$ & $30.42 \pm 5.46$ \\
Moisture content $\left(\mathrm{g} 100^{-1}\right)$ & $74.48 \pm 3.79$ & $2.06 \pm 0.06$ \\
Total dietary fiber $\left(\mathrm{g} 100^{-1}\right)$ & $6.15 \pm 0.03$ & $44.21 \pm 0.66$ \\
Lipids $\left(\mathrm{g} 100^{-1}\right)$ & $4.11 \pm 0.26$ & $8.97 \pm 0.99$ \\
Proteins $\left(\mathrm{g} 100^{-1}\right)$ & $3.13 \pm 0.98$ & $1.07 \pm 0.01$ \\
Ash $\left(\mathrm{g} 100^{-1}\right)$ & $1.74 \pm 0.08$ & $13.26 \pm 1.21$ \\
Carbohydrates $\left(\mathrm{g} 100^{-1}\right)$ & $10.38 \pm 2.57$ & $486.85 \pm 1.97$ \\
Caloric value $\left({\left.\mathrm{Kcal} 100^{-1}\right)}^{\text {Cat }}\right.$ ) & $91.10 \pm 9.27$ & \\
\hline
\end{tabular}

Values are expressed in fresh matter (mean of ten repetitions \pm standard deviation). nd: not detected. commonly known as good sources of these compounds, for example, coconut (Cocos nucifera L.) which has a calorific value

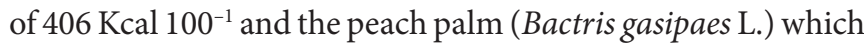

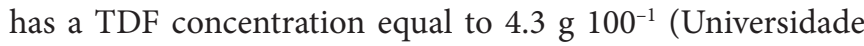
Estadual de Campinas, 2011; Rodriguez-Amaya et al., 2008). These results indicated that the licuri fruit is a good option for individuals who need to gain weight. However, for individuals with overweight its consumption should be monitored.

\subsection{Carotenoids and vitamins}

\section{Qualitative composition}

The analysis methods used allowed for good resolution of the peaks, which guaranteed proper identification and quantification of carotenoids and vitamins in the licuri fruit. The pulp showed $\beta$-carotene, $\beta$-cryptoxanthin, lycopene, AA, DHA, $\alpha$-tocopherol, $\alpha$-tocotrienol, $\beta$-tocopherol and $\gamma$-tocotrienol. The kernel presented $\alpha$-carotene, $\beta$-carotene, $\beta$-cryptoxanthin, $\alpha$-tocopherol, $\alpha$-tocotrienol, $\beta$-tocopherol, $\beta$-tocotrienol, $\gamma$-tocopherol and $\gamma$-tocotrienol.

\section{Quantitative composition}

There are few reports in literature on the presence of carotenoids and vitamins in licuri fruits (Crepaldi et al., 2001; Miranda, 2011), but they differ with regards to the analysis methods used in our study, making it difficult to compare the results.

In the present study the concentration of $\beta$-carotene was featured in pulp $\left(8.94 \mathrm{mg} 100 \mathrm{~g}^{-1}\right)$. If attributing $100 \%$ of vitamin A activity to this carotenoid (Universidade Estadual de Campinas, 2011), the pulp showed a vitamin A value (758.75 RAE $100 \mathrm{~g}^{-1}$ ) (Table 3), higher than pumpkin (139 RAE $100 \mathrm{~g}^{-1}$ ) and carrot (663 RAE $\left.100 \mathrm{~g}^{-1}\right)$, fruits considered sources of this vitamin (Miranda, 2011; Universidade Estadual de Campinas, 2011).

The main component of vitamin $\mathrm{C}$ in the licuri fruit was AA, found only in the pulp. The content in the present study corresponded to $60 \%$ of the concentration observed by Miranda (2011), who found values of $4.30 \mathrm{mg} 100 \mathrm{~g}^{-1}$ in fruits collected in the Brazilian state of Paraíba. Regarding the concentration of vitamin $E, \alpha-, \beta-, \gamma$ - tocopherols and tocotrienols were identified, highlighting $\beta$-tocotrienol as the main component found in the kernels.

Although the kernel presented the highest concentration of vitamin E, they were not considered a source, since only $2.8 \%$ of the compounds encountered were in the form of $\alpha$-tocopherol. However, we emphasize the importance of other tocopherols and tocotrienols found in the pulp, since they can prevent or minimize the damage caused by free radicals associated with diseases such as cancer, arthritis, cataracts, and aging (Sen et al., 2010). The pulp, although it had a total vitamin E concentration less than the kernel, showed a high a-tocopherol concentration $\left(486.62 \mu \mathrm{g} 100^{-1}\right)$. This compound represented $89.5 \%$ of the entire concentration found in the pulp, but insufficient to be considered a source of this vitamin. 
Table 3. Concentration of carotenoids and vitamins in licuri fruits (Syagrus coronata (Mart.) Becc) found in the Atlantic Forest of Minas Gerais, Brazil.

\begin{tabular}{|c|c|c|c|c|}
\hline Compounds & Pulp & $\%$ & Kernel & $\%$ \\
\hline Vitamina A (RAE $\left.\mu \mathrm{g} 100 \mathrm{~g}^{-1}\right)$ & $758.75 \pm 178.75$ & 100 & $176.03 \pm 65.25$ & 100 \\
\hline Carotenoids (mg 100-1) & $9.28 \pm 2.12$ & 100 & $3.14 \pm 1.57$ & 100 \\
\hline$\alpha$-carotene $\left(\mathrm{mg} 100^{-1}\right)$ & nd & -- & $1.88 \pm 0.34$ & 59.87 \\
\hline$\beta$-carotene $\left(\mathrm{mg} 100^{-1}\right)$ & $8.94 \pm 2.11$ & 96.34 & $1.13 \pm 0.68$ & 35.99 \\
\hline$\beta$-cryptoxanthin $\left(\mathrm{mg} 100^{-1}\right)$ & $0.28 \pm 0.04$ & 3.02 & $0.13 \pm 0.01$ & 4.14 \\
\hline Lycopene (mg 100-1) & $0.05 \pm 0.03$ & 0.64 & nd & -- \\
\hline Total vitamin $\mathrm{C}\left(\mathrm{mg} 100^{-1}\right)$ & $3.66 \pm 0.78$ & 100 & nd & -- \\
\hline $\mathrm{AA}\left(\mathrm{mg} 100^{-1}\right)$ & $2.84 \pm 0.67$ & 77.59 & nd & -- \\
\hline DHA (mg $\left.100^{-1}\right)$ & $0.82 \pm 0.44$ & 22.41 & nd & -- \\
\hline Total vitamin $\mathrm{E}\left(\mu \mathrm{g} 100^{-1}\right)$ & $543.58 \pm 33.45$ & 100 & $1302.50 \pm 381.94$ & 100 \\
\hline a-tocopherol $\left(\mu \mathrm{g} 100^{-1}\right)$ & $486.62 \pm 21.13$ & 89.52 & $36.48 \pm 4.44$ & 2.80 \\
\hline a-tocotrienol $\left(\mu \mathrm{g} 100^{-1}\right)$ & $8.95 \pm 0.68$ & 1.65 & $364.34 \pm 30.81$ & 27.97 \\
\hline$\beta$-tocopherol $\left(\mu \mathrm{g} 100^{-1}\right)$ & $38.79 \pm 10.01$ & 7.14 & $10.65 \pm 1.84$ & 0.82 \\
\hline$\beta$-tocotrienol $\left(\mu \mathrm{g} 100^{-1}\right)$ & nd & -- & $795.09 \pm 104.57$ & 61.04 \\
\hline$\gamma$-tocopherol $\left(\mu \mathrm{g} 100^{-1}\right)$ & nd & -- & $6.70 \pm 4.30$ & 0.51 \\
\hline$\gamma$-tocotrienol $\left(\mu \mathrm{g} 100^{-1}\right)$ & $9.22 \pm 4.39$ & 1.69 & $89.24 \pm 8.26$ & 6.86 \\
\hline
\end{tabular}

Values are expressed in fresh matter (mean of five repetitions \pm standard deviation).nd: not detected.

Sganzeria (2010), in a study conducted in Rio Grande do Sul, did not detect the presence of tocopherols in kernels in any species, although the pulp presented $426.00 \mu \mathrm{g} 100^{-1}$ of total tocopherols, equivalent to $81 \%$ of the concentration found in our study. A direct relationship was observed between concentrations of vitamin $\mathrm{E}$ and lipids in the kernels and pulp of the licuri fruit.

\section{Concentration of minerals}

In the present study the main minerals in the pulp were $\mathrm{K}$, $\mathrm{Fe}$ and $\mathrm{Mn}$, while in the kernel were $\mathrm{P}, \mathrm{K}, \mathrm{Mg}, \mathrm{Fe}, \mathrm{Zn}$ and $\mathrm{Mn}$. Se was not found in any of the samples, while $\mathrm{Cr}$ was found only in the pulp (Table 4).

Miranda (2011) observed Zn concentrations in the pulp and kernels of licuri fruits from the state of Paraíba

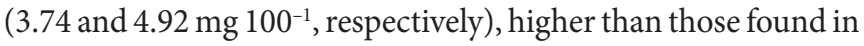
this study. Licuri fruits from the Brazilian Northeast showed Fe concentrations (pulp: $1.48 \mathrm{mg} \mathrm{100}^{-1}$, and kernels: $1.19 \mathrm{mg} \mathrm{100}^{-1}$ ) lower than those observed in the present study (Miranda, 2011).

\section{Potential contribution of licuri fruit to meet nutritional recommendations}

The potential contribution of fractions from the licuri fruit to meet the recommendations of vitamins and minerals for adult men (19 to 30 years old) are presented in Table 5.

Aproximately, 77 and $20 \mathrm{~g}$, respectively, are needed to provide the pulp $(70 \mathrm{kcal})$ and kernel $(100 \mathrm{kcal})$ portions. The pulp was considered a source of carbohydrates and good source of fiber. Considering the recommendation of vitamin A (Institute of Medicine, 2011), pulp of the licuri fruit showed to be an excellent source of this vitamin, contributing to $64.9 \%$ of the recommendation. Licuri fruits were not considered sources of vitamin $C$, since the quantities found were very low.
Table 4. Concentration of minerals in licuri fruits (Syagrus coronata (Mart.) Becc) found in the Atlantic Forest of Minas Gerais, Brazil.

\begin{tabular}{ccc}
\hline Minerals $\left(\mathrm{mg} \mathrm{100} 0^{-1}\right)$ & Licuri fruit (pulp) & Licuri fruit (kernel) \\
\hline $\mathrm{P}$ & $0.65 \pm 0.13$ & $2.85 \pm 0.14$ \\
$\mathrm{~K}$ & $17.50 \pm 3.34$ & $4.91 \pm 0.21$ \\
$\mathrm{Ca}$ & $0.86 \pm 0.12$ & $0.68 \pm 0.04$ \\
$\mathrm{Mg}$ & $0.71 \pm 0.08$ & $1.54 \pm 0.06$ \\
$\mathrm{Cu}$ & $0.69 \pm 0.10$ & $0.97 \pm 0.03$ \\
$\mathrm{Fe}$ & $3.81 \pm 1.76$ & $3.36 \pm 0.47$ \\
$\mathrm{Zn}$ & $0.95 \pm 0.06$ & $2.11 \pm 0.11$ \\
$\mathrm{Mn}$ & $3.40 \pm 1.37$ & $6.14 \pm 0.50$ \\
$\mathrm{Na}$ & $0.12 \pm 0.02$ & $0.15 \pm 0.04$ \\
$\mathrm{Cr}$ & $0.03 \pm 0.01$ & $\mathrm{nd}$ \\
$\mathrm{Se}$ & $\mathrm{nd}$ & $\mathrm{nd}$ \\
$\mathrm{Mo}$ & $0.06 \pm 0.01$ & $0.07 \pm 0.04$ \\
\hline
\end{tabular}

Values are expressed in fresh matter; mean of 3 repetions; data presented in mean (rounded to two decimal places) \pm standard deviation; nd: not detected.

Although the licuri kernel presented a high concentration of vitamin $\mathrm{E}$, this was not considered a source because it contains only $36.48 \mu \mathrm{g} 100^{-1}$ in the form of $\alpha$-tocopherol, which is currently the only component considered for calculation of the recommendations (Müller et al., 2010).

The kernel was considered an excellent source of $\mathrm{Cu}$, while the pulp was considered a source of $\mathrm{Zn}$. The kernel was also considered a potential source of $\mathrm{Fe}$, while the pulp an excellent source of this nutrient.

Both the pulp and kernel of the licuri fruit were considered excellent sources of Mn, even surpassing the DRIs for intake of these nutrients, but without exceeding the untolerable level (UL) for intake by adults between 19 to 30 years old ( $\mathrm{UL}=11 \mathrm{mg} /$ day). Pulp of the licuri fruit showed to be a source of $\mathrm{Cr}$ and excellent source of Mo. 
Table 5. Potential contribution of licuri fruits (Syagrus coronata (Mart.) Becc) found in the Atlantic Forest of Minas Gerais, Brazil, for supplying of daily nutrient recommendations*.

\begin{tabular}{ccc}
\hline \multirow{2}{*}{ Nutrients } & \multicolumn{2}{c}{$\%$ contribution } \\
\cline { 2 - 3 } Carbohydrates & 6.13 & Kernel $\left(1\right.$ portion $\left.=20 \mathrm{~g}^{\star}\right)$ \\
Proteins & 4.29 & 2.09 \\
Total Dietary & 12.43 & 3.20 \\
Fibers & & 1.08 \\
Vitamin A & 64.91 & \\
Vitamin C & 3.13 & 3.91 \\
Vitamin E & 2.50 & $\mathrm{Nd}$ \\
$\mathrm{P}$ & 0.07 & 0.49 \\
$\mathrm{~K}$ & 0.3 & 0.08 \\
$\mathrm{Ca}$ & 0.07 & 0.02 \\
$\mathrm{Mg}$ & 0.14 & 0.01 \\
$\mathrm{Cu}$ & 59 & 0.08 \\
$\mathrm{Fe}$ & 37 & 21 \\
$\mathrm{Zn}$ & 6.65 & 8.4 \\
$\mathrm{Mn}$ & 113 & 3.83 \\
$\mathrm{Na}$ & 0.004 & 53.4 \\
$\mathrm{Cr}$ & 66.0 & 0.002 \\
$\mathrm{Se}$ & $\mathrm{nd}$ & $\mathrm{Nd}$ \\
$\mathrm{Mo}$ & 102 & $\mathrm{Nd}$ \\
\hline
\end{tabular}

${ }^{*}$ Calculated based on the Recommended Dietary Allowance of minerals for adult men between 19 and 30 years old (Institute of Medicine, 2011), based on a portion of pulp and kernel which provide 70 and $100 \mathrm{kcal}$, respectively (Brasil, 2008), nd: not detected. **( $\alpha$-tocoferol).

\section{Conclusions}

The present study shows the first results on the concentration of nutrients in these fruits in the Atlantic Forest region, and can help to fill a gap in information regarding its nutritional composition.

The licuri fruits analyzed in this study exhibited high pulp yield. Their nutritional value was considered excellent due to the presence of vitamin $\mathrm{C}$ and $\mathrm{E}$, carotenoids and minerals, and it was an excellent source of vitamin $\mathrm{A}, \mathrm{Cu}, \mathrm{Fe}, \mathrm{Mn}, \mathrm{Cr}$ and Mo. The caloric density was higher than that of many fruits consumed in Brazil, and it also presented high concentrations of total dietary fiber and lipids. The nutritional value and wide availability of this fruit make it an important tool for reducing food insecurity and improving nutrition of individuals residing near the Atlantic Forest, especially in rural households, since its consumption is part of the eating habit of these families.

\section{Acknowledgements}

The authors thank the FUNARBE, FAPEMIG, CNPq and CAPES for providing scholarships and financial support for performing this study.

\section{References}

Association of Official Analytical Chemists - AOAC. (2010). Official methods of analysis (17th ed.). Washington: AOAC.
Betoret, E., Betoret, N., Vidal, D., \& Fito, P. (2011). Functional foods development: trends and technologies. Trends in Food Science \& Technology, 22(9), 498-508. http://dx.doi.org/10.1016/j.tifs.2011.05.004.

Bezerra, F. C. (2003). Produção de mudas de hortaliças em ambiente protegido (1st ed.). Fortaleza: EMBRAPA.

Bora, P. S., Rocha, R. V. M., Narain, N., Moreira-Monteiro, A. C., \& Moreira, R. A. (2003). Characterization of principal nutritional components of Brazilian oil palm (Eliaes guineensis) fruits. Bioresource Technology, 87(1), 1-5. http://dx.doi.org/10.1016/S09608524(02)00223-7. PMid:12733568.

Brasil, Ministério da Saúde. (2008). Guia alimentar para a população brasileira: promovendo a alimentação saudável. Brasília.

Campos, F. M., Ribeiro, S. M. R., Della Lucia, C. M., Pinheiro-Sant'Ana, H. M., \& Stringheta, P. C. (2009). Optimization of methodology to analyze ascorbic and dehydroascorbic acid in vegetables. Quimica Nova, 32(1), 87-91. http://dx.doi.org/10.1590/S0100-40422009000100017.

Cardoso, L. M., Bedetti, S. F., Ribeiro, S. M. R., Esteves, E. A., \& Pinheiro-Sant'Ana, H. M. (2013a). 'Jatobá do cerrado' (Hymenaea stigonocarpa): chemical composition, carotenoids and vitamins in an exotic fruit from the Brazilian Savannah. Fruits, 68(2), 95-107. http://dx.doi.org/10.1051/fruits/2013056.

Cardoso, L. M., Reis, B. L., Hamacek, F. R., \& Pinheiro-Sant'Ana, H. M. (2013b). Chemical characteristics and bioactive compounds of cooked pequi fruits (Caryocar brasiliense Camb.) from the Brazilian Savannah. Fruits, 68(1), 3-14. http://dx.doi.org/10.1051/fruits/2012047.

Crepaldi, I. C., Almeida-Muradian, L. B., Rios, M. D. G., Penteado, M. V. C., \& Salatino, A. (2001). Composição nutricional do fruto de licuri (Syagrus coronata (Mart.) Becc.). Revista Brasileira de Botanica, 24(2), 155-159. http://dx.doi.org/10.1590/S0100-84042001000200004.

Drumond, M. A. (2007). Licuri Syagrus coronata (Mart.) Becc (1st ed.). Petrolina: EMBRAPA.

Faria, J. P., Arellano, D. B., Grimaldi, R., Silva, L. C. R., Vieira, R. F., Silva, D. B., \& Agostini-Costa, T. S. (2008). Caracterização química da amêndoa de coquinho-azedo (Butia capitata var capitata). Revista Brasileira de Fruticultura, 30(2), 549-552. http://dx.doi.org/10.1590/ S0100-29452008000200049.

Frary, C. D., \& Johnson, R. K. (2005). Energia. In L. K. Mahan \& S. Escott-Stump (Eds.), Krause: alimentos, nutrição e dietoterapia (Chap. 3, pp. 20-34). São Paulo: Rocca.

Gomes, J. C., \& Oliveira, G. F. (2011). Fotometria de chama e espectrofotometria de absorção atômica. In J. C. Gomes \& G. F. Oliveira (Eds.), Análises físico-químicas de alimentos (Chap. 4, pp. 47-52). Viçosa: Editora da Universidade Federal de Viçosa.

Institute of Medicine - IOM. (2011). Dietary Reference Intakes (DRIs): vitamin $a$, vitamin $k$, arsenic, boron, cromium, copper, iodine, iron, manganese, molybdenium, nickel, silicon, vanadium and zinc. Washington.

Instituto Adolfo Lutz - IAL. (2005). Métodos físico-químicos para análise de Alimentos (3rd ed.). São Paulo.

Kinupp, V. F., \& Barros, I. B. I. (2004). Levantamento de dados e divulgação do potencial de plantas alimentícias alternativas no Brasil. Horticultura Brasileira, 22(2), 17-25.

Lorenzi, H., Bacher, L., Lacerda, M., \& Sartori, S. (2006). Frutas brasileiras e exóticas cultivadas (de consumo in natura). São Paulo: Instituto Plantarum de Estudos da Flora.

Miller, A. J., \& Gross, B. L. (2011). From forest to field: perennial fruit crop domestication. American Journal of Botany, 98(9), 1389-1414. http://dx.doi.org/10.3732/ajb.1000522. PMid:21865506. 
Miranda, K. E. S. (2011). Qualidade e atividade antioxidante de fruto e seu óleo de genótipos do licurizeiro (Syagrus coronata) (Master's Thesis). Universidade Federal da Paraíba, João Pessoa.

Müller, L., Theile, K., \& Böhm, V. (2010). In vitro antioxidant activity of tocopherols and tocotrienols and comparison of vitamin $\mathrm{E}$ concentration and lipophilic antioxidant capacity in human plasma. Molecular Nutrition \& Food Research, 54(5), 731-742. http://dx.doi. org/10.1002/mnfr.200900399. PMid:20333724.

Philippi, S. T. (2008). Pirâmide dos alimentos: fundamentos básicos da nutrição (1st ed.). Barueri: Manole.

Pilla, M. A. C., \& Amorozo, M. C. M. (2009). O conhecimento sobre os recursos vegetais alimentares em bairros rurais no Vale do Paraíba, SP, Brasil. Acta Botanica Brasílica, 23(4), 1190-1201. http://dx.doi. org/10.1590/S0102-33062009000400030.

Pinheiro-Sant'Ana, H. M., Guinazi, M., Oliveira, D. S., Della Lucia, C. M., Reis, B. L., \& Brandão, S. C. C. (2011). Method for simultaneous analysis of eight vitamin $\mathrm{E}$ isomers in various foods by high performance liquid chromatography and fluorescence detection. Journal of Chromatography. A, 1218(47), 8496-8502. http://dx.doi. org/10.1016/j.chroma.2011.09.067. PMid:22014383.

Pinheiro-Sant’Ana, H. M., Stringheta, P. C., Brandão, S. C. C., \& Azeredo, R. M. C. (1998). Carotenoid retention and vitamin A value in carrot (Daucus carota L.) prepared by food service. Food Chemistry, 61(12), 145-151. http://dx.doi.org/10.1016/S0308-8146(97)00084-8.

Rockenbach, I. I., Rodrigues, E., Cataneo, C., Gonzaga, L. V., Lima, A., Mancini-Filho, J., \& Fett, R. (2008). Ácidos fenólicos e atividade oxidante em fruto de Physalis peruviana L. Alimentos e Nutrição, 19(3), 271-276.
Rodriguez-Amaya, D. B., Kimura, M., \& Amaya-Farfan, J. (2008). Fontes Brasileiras de Carotenoides: Tabela brasileira de composição de carotenoides em alimentos. Brasília: Ministério do Meio Ambiente.

Rodriguez-Amaya, D. B., Raymundo, L. C., Lee, T. C., Simpson, K. L., \& Chichester, C. O. (1976). Carotenoid changes in ripening Momordica charantia. Annual Botanic, 167(40), 615-624.

Rufino, M. U. L., Costa, J. T. M., Silva, V. A., \& Andrade, L. H. C. (2008). Conhecimento e uso do ouricuri (Syagrus coronata) e do babaçu (Orbignya phalerata) em Buíque, PE, Brasil. Acta Botanica Brasílica, 22(4), 1141-1149. http://dx.doi.org/10.1590/S010233062008000400025 .

Santos, T. C., Nascimento-Júnior, J. E., \& Prata, A. P. N. (2012). Frutos da Caatinga de Sergipe utilizados na alimentação humana. Scientia Plena, 8(1), 1-7.

Sen, S., Chakraborty, R., Sridhar, C., Reddy, Y. S. R., \& Biplab, De. (2010). Free radicals, antioxidants, diseases and phytomedicines: current status and future prospect. International Journal of Pharmaceutical Sciences Review and Research, 3(1), 91-100.

Sganzeria, M. (2010). Caracterização físico-química e capacidade antioxidante do butiá (Master's Dissertation). Universidade Federal de Pelotas, Pelotas.

Universidade Estadual de Campinas - UNICAMP. (2011). Tabela brasileira de composição de alimentos: TACO (4th ed.). Campinas: UNICAMP/NEPA.

Vallilo, M. I., Garbelotti, M. L., Oliveira, E., \& Lamardo, L. C. A. (2005). Características físicas e químicas dos frutos do cambucizeiro (Campomanesia phaea). Revista Brasileira de Fruticultura, 27(2), 241-244. http://dx.doi.org/10.1590/S0100-29452005000200014. 